\title{
Contrasting responses of DOM leachates to photodegradation observed in plant species collected along an estuarine salinity gradient
}

\author{
Tracey Schafer (D) Leanne Powers • Michael Gonsior • K. R. Reddy • \\ Todd Z. Osborne
}

Received: 11 March 2020/ Accepted: 6 January 2021/Published online: 4 February 2021

(C) The Author(s) 2021

\begin{abstract}
A series of abiotic processes affected by salinity changes involve light-mediated reactions and different degradation pathways of organic compounds, including altered photo-oxidation, photodegradation, and photolysis of organic matter (OM). Sunlight is known to degrade, oxidize, or mineralize dissolved organic matter (DOM) in waterways, creating large changes in compositional structure of DOM near the water surface and ultimately in the mixed layer. DOM derived from various vegetation types has differing levels of susceptibility to photolytic degradation depending on initial chemical composition and
\end{abstract}

Supplementary Information The online version of this article (https://doi.org/10.1007/s10533-021-00756-0) contains supplementary material, which is available to authorized users.

Responsible Editor: Sujay Kaushal.

T. Schafer $(\bowtie) \cdot$ T. Z. Osborne

Estuarine Biogeochemistry Laboratory, Whitney

Laboratory for Marine Biosciences, University of Florida,

St. Augustine, FL, USA

e-mail: tschafer25@ufl.edu

T. Schafer · K. R. Reddy · T. Z. Osborne

Wetland Biogeochemistry Laboratory, Soil and Water

Sciences Department, University of Florida, Gainesville,

FL, USA

L. Powers · M. Gonsior

Chesapeake Biological Laboratory, University of

Maryland Center for Environmental Science, Solomons,

MD, USA in what matrix degradation takes place (e.g., salinity). The effect of sunlight and salinity on degradation of leached DOM derived from three dominant vegetative species, Avicennia germinans, Juncus romerianus, and Taxodium distichum, along a riverine continuum in northeast Florida was determined. Leachates from these three sources in a deionized or seawater matrix were irradiated in a continuous flow-through photolytic system over the course of $20 \mathrm{~h}$. Avicennia germinans and Juncus roemerinaus DOM readily degraded as indicated by decreases in absorbance across all wavelengths during the irradiation period, while Taxodium distichum DOM was found to increase in absorbance across all wavelengths in the freshwater matrix, but not in seawater. PARAFAC analysis indicated differences in photochemical components and $\%$ change of absorbance and fluorescence over time indicate the importance and variability of individual contributions to the DOM pool across an estuarine continuum. This work characterizes the photochemical properties of three individual DOM sources, exhibits the need for further research on this topic, and explores the salinity effect on photodegradation of DOM from unique plant-derived DOM.

Keywords Photochemistry - DOM - PARAFAC . Aquatic continuum 


\section{Introduction}

Photo-reactive components of DOM play a vital biogeochemical and ecological role as a source of nutrients and organic substrates, as well as a means of attenuating sunlight. Chromophoric dissolved organic matter (CDOM) and a portion of CDOM specifically referred to as fluorescent DOM (fDOM) primarily make up these photo-reactive species and are structurally complex, consisting of an unknown array of conjugated aromatic compounds (Wetzel et al. 1995; Engelhaupt et al. 2003; Osburn and Stedmon 2011; Chen and Jaffé 2016). CDOM shields aquatic organisms from harmful UV radiation, and upon breakdown can release nutrients for phytoplankton that fuels aquatic food webs and microorganisms that drive biogeochemical cycling (Williamson et al. 2001; Miller et al. 2002; Walsh et al. 2003; Stedmon et al. 2007; Vahatalo and Jarvinen 2007). Although well documented in the literature, photochemical degradation of CDOM remains highly variable with studies reporting conflicting evidence on effects of photodegradation rates, including both release and inhibition of greenhouse gas emissions, such as $\mathrm{CO}_{2}$ (Johannessen and Miller 2001; Stubbins et al. 2006; Toole et al. 2006). Therefore, further studies are needed to understand the nuances of photodegradation behavior of different CDOM source material, especially related to specific source DOM derived from abundant plant communities.

Chromophores and fluorophores that make up CDOM, as well as FDOM, are derived from vegetative sources, and these sources of OM more rapidly enter the DOM pool during disturbance events (e.g., floods) that can rapidly transport OM into waterways. When this vegetative material is added to aquatic systems (or transported into waterways), plant-derived DOM begins to leach into the water column, creating DOM in a very early diagenetic state (Wheeler et al. 2017). A few studies have previously observed the effects of environmental factors, such as $\mathrm{pH}$ and senescence, on the effect of photo-degradation of leaf litter leachates in a variety of tree species, including lodgepole pine (Pinus contorta), sugar maple (Acer saccharum), white spruce (Picea glauca), silver maple (Acer saccharinum), American beech (Fagus grandifolia Ehrh.), yellow poplar (Liriodendron tulipifera L.), and red mangrove (Rhizophera mangle) (Shank et al. 2010; Beggs and Summers 2011; Cuss et al.
2014; Wheeler et al. 2017). However, none of these studies directly investigated the effects of salinity on leaf litter leachates. In addition, a study by Cuss et al. 2014 using fluorescence analyzed by parallel factor analysis (PARAFAC) determined that individual DOM source material did not behave the same under equivalent experimental treatments; therefore, calling for more studies examining source-specific material.

Since bulk DOM in waterways will have a much more complex and altered chemical composition than source-specific material, it is necessary to look at source-specific DOM in order to determine each source's contribution to the DOM photo-reactive pool. Some studies used fluorescence to determine changes to $\mathrm{fDOM}$ and CDOM pools, but there has been very limited research exploring how source-specific DOM is photochemically affected (Larsen et al. 2010; Osburn et al. 2012). Therefore, dominant vegetation types were leached in this study to create sourcespecific DOM and observe salinity effects on photoreactivity of these specific DOM sources. It is hypothesized that an increase in salinity will rapidly enhance photo-degradation of source-specific DOM, and each source will have unique absorbance and fluorescence properties that react differently under varying salinity regimes. The primary objective of this research was to determine if salinity will change the photochemical properties of DOM derived from three unique plant DOM sources, Avicennia germinans, Juncus roemerianus, and Taxodium distichum, originating along an aquatic salinity gradient.

\section{Study site and methods}

Study site description

The study site consists of a transition zone between an estuary and a black-water river in St. Augustine, Florida. Pellicer Creek is the blackwater river that is the primary tributary of the Matanzas River (also the Intracoastal Estuary) (Figs. 1, 2). The site spans approximately $15 \mathrm{~km}$ inland and is tidally influenced with daily salinity fluctuations (0-35), influencing dominant vegetation species throughout the study site. Black mangrove (Avicennia germinans) is the dominant species within the Matanzas River at the eastern edge of the site that grows in salinities between 20 and 35 at this location. Further inland (at salinities 10-25), 

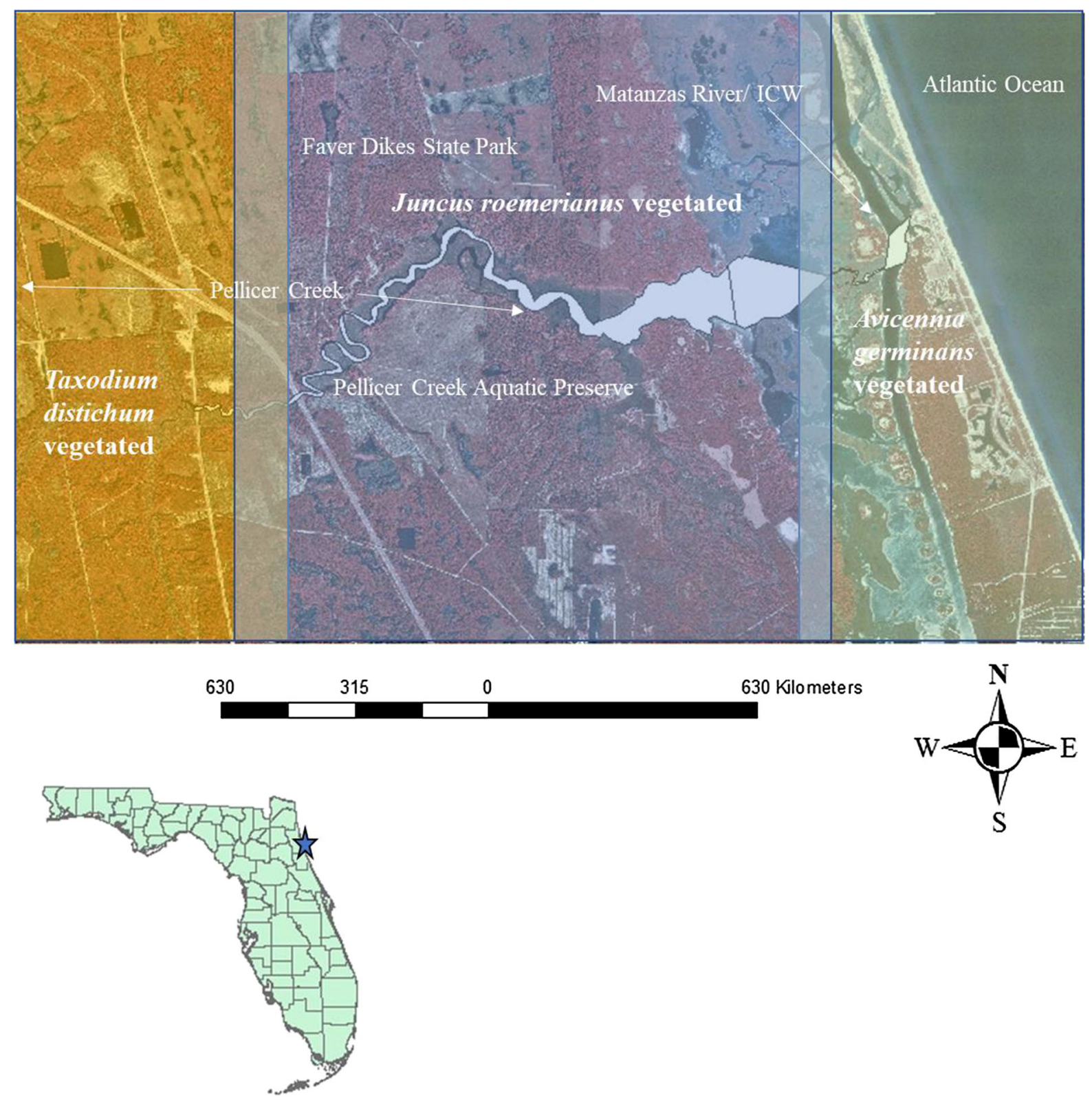

\section{County Boundaries: FGDL 1:24,000 \\ Orthophotos: Western Mapping Center (1996) 1:24,000}

Fig. 1 Map of the study site near St. Augustine, FL where vegetation was collected for this study from the Intracoastal Waterway into the fresher headwaters of Pellicer Creek within the Pellicer Creek Aquatic Preserve within the Guana-Tolomato

the marsh grass black needle rush (Juncus roemerianus) is the overwhelmingly dominant vegetative type, spanning a $10 \mathrm{~km}$ section of the waterway. In the farthest western $3 \mathrm{~km}$ of the site, where salinity is
Matanzas National Estuarine Research Reserve. Vegetation was collected from within each of the three sections, including Avicennia germinans, Juncus romerianus, and Taxodium disticum

primarily 0 , a mix of freshwater species exist with bald cypress (Taxodium distichum) as one of the most prolific species in this area. 

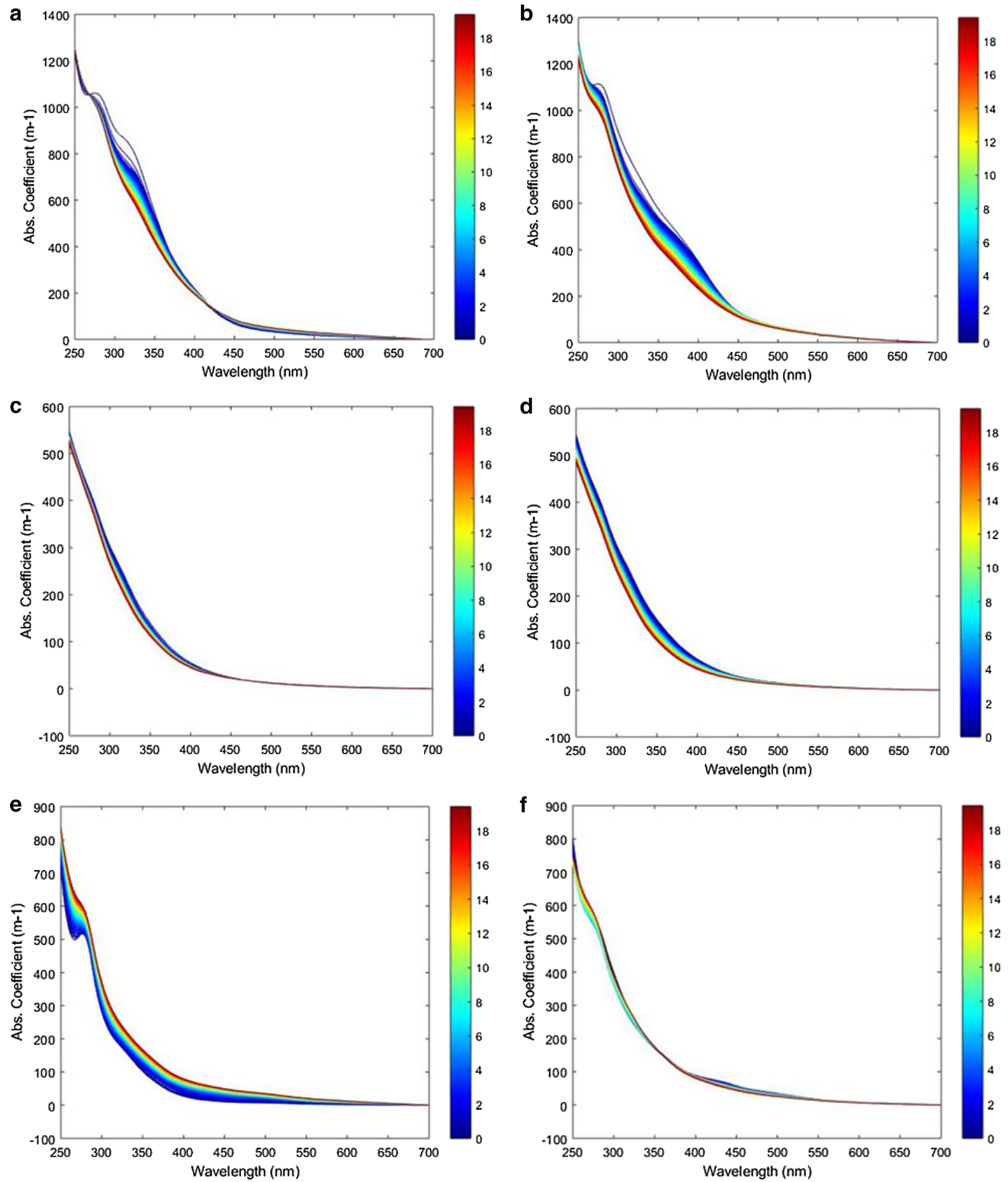

Fig. 2 Absorbance coefficents $\left(\mathrm{m}^{-1}\right)$ in fresh and saltwater diluted samples over $\lambda=250-700 \mathrm{~nm}$. a Avicennia germinans fresh water b Avicennia germinans salt water c Juncus

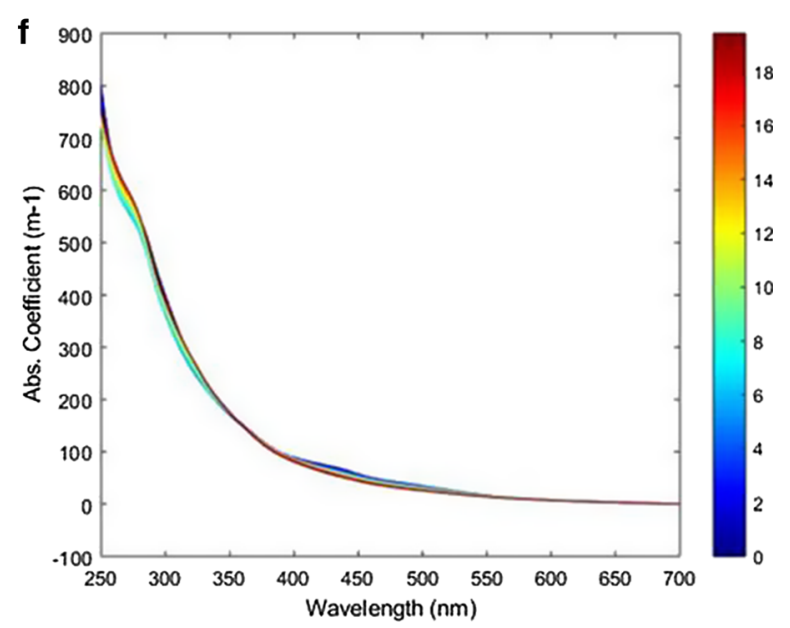

roemerianus fresh water d Juncus roemerianus salt water e Taxodium distichum fresh water f Taxodium distichum salt water as irradiated over $20 \mathrm{~h}$. Color bar represents time in hours 
Leachate preparation

Senescent leaves were collected from Taxodium distichum ( $T$. distichum), Juncus roemerianus (J. roemerianus), and Avicennia germinans (A. germinans). Following the method described by Osborne et al. (2007) for leachate preparation, $50 \mathrm{~g}$ of air-dried senescent leaves for each species were added to $2 \mathrm{~L}$ of deionized water or to autoclaved $1 \mu \mathrm{m}$ filtered seawater (salinity $=35$ ). Leaves were leached for $24 \mathrm{~h}$ and filtered through $0.45 \mu \mathrm{m}$ glass fiber filters. Leachates were then refrigerated at $4{ }^{\circ} \mathrm{C}$ until photo irradiation. Before irradiation experiments, the following dilutions were calculated for assurance that absorbance values would remain below $1 \mathrm{~m}^{-1}$ at $230 \mathrm{~nm}$; dilution ratios were J. roemerianus 1: 3, A. germinans 1: 10, and T. distichum 1:6.

Photo-degradation experiments

Leachates were irradiated over a 20 -h period using a continuous flow-through custom-designed photodegradation system described in detail elsewhere (Timko et al. 2015). Leachate sub-samples of $15 \mathrm{~mL}$ were placed in a $50 \mathrm{~mL}$ three-neck round bottom flask with an intake and output tubing to consistently uptake leachate in small amounts and return it to the vial after irradiation. After rinsing the tubing with at least $300 \mathrm{~mL}$ of distilled deionized water (also used for original blank), $40 \mathrm{~mL}$ of sample were pumped through the flow-through system to avoid dilution from residual DI. An Orian 8220BNWP micro-electrode $\mathrm{pH}$ stat was also placed into the flask to monitor $\mathrm{pH}$ and an attached J-kem Infinity 2 reaction controller was used to make microliter adjustments to $\mathrm{pH}$ with $0.1 \mathrm{M} \mathrm{HCl}$ and $0.1 \mathrm{M} \mathrm{NaOH}$ to stabilize and maintain $\mathrm{pH}$ between 7.7 and 8.0.

Sample was pumped from the $50 \mathrm{~mL}$ vial and was fully irradiated under a Sol2A class ABA solar simulator (Newport Oriel SolABA) in a $101 \mathrm{~cm}^{2}$ custom-designed borosilicate glass Archimedean spiral (SCHOTT Borofloat, Hellma Analytics, 70 to 85\% transmission between 300 and $350 \mathrm{~nm}$, and $85 \%$ transmission at wavelengths $>350$ ) with a $2 \mathrm{~mm}$ wide by $1 \mathrm{~mm}$ deep channel to avoid inner filter effects (Timko et al. 2015 above). Under these experimental conditions, integrated photon doses between $\sim 330$ and $380 \mathrm{~nm}$ were approximately $145 \mu$ Einsteins $\mathrm{m}^{-2} \mathrm{~s}^{-1}$, determined by $\mathrm{NO}_{2}$ actinometry and methods described previously (Jankowski et al. 1999, 2000). Based on modeled solar irradiance from 330 to $380 \mathrm{~nm}$ from the System for Transfer of Atmospheric Radiation model (Ruggaber et al. 1994) calculated just below the sea surface (Fichot and Miller 2010), $20 \mathrm{~h}$ irradiation in this system is equivalent to 3 days exposure at $30^{\circ} \mathrm{N}$ in mid-July.

After irradiation, the sample flowed through a $1 \mathrm{~cm}$ quartz cuvette in an Aqualog spectrofluorometer (Horiba Instruments). Absorbance/excitation was recorded between 230 and $700 \mathrm{~nm}$ wavelengths at $3 \mathrm{~nm}$ intervals and emission was recorded between 290 and $600 \mathrm{~nm}$ at $\sim 3 \mathrm{~nm}$ intervals to create excitation emission matrices (EEMs). Ultrapure water (18 $\mathrm{M} \Omega$ Milli-Q water) served as the fluorescence and absorbance blank and all fluorescence spectra were normalized to the area of water Raman peak. Absorbance and EEMs were collected from the flow through every $20 \mathrm{~min}$ for $20 \mathrm{~h}$, resulting in 60 absorbance and EEM spectra. Because the Aqualog records absorbance and fluorescence together, fluorescence spectra were corrected for inner filter effects and resulting spectra were corrected for first and second order Raleigh scattering using the FLToolbox 1.91 (Zepp et al. 2004) in Matlab® 2018b (Mathworks, Natick, MA,USA). Raw absorbance was corrected for any offsets between seawater and the pure water blank and/or instrument drift by subtracting all spectra by their absorbance at $700 \mathrm{~nm}$. Corrected absorbance was then converted to the Naperian absorption coefficient by multiplying spectra by 2.303 and dividing by the cell pathlength $(0.01 \mathrm{~m})$. Difference absorption coefficient spectra were calculated by subtracting all spectra from that at time zero (before irradiation).

Statistical analysis

EEM spectra were further analyzed using the DREEM toolbox in Matlab for parallel factor analysis (PARAFAC), which deconvolutes EEMS into individual components, each with their own excitation and emission spectrum (Murphy et al. 2013). PARAFAC models were generated for each vegetation type by running an overall model (combined DI and saltwater results) or DI and saltwater specific models. The number of PARAFAC components in each model were chosen following the methods of Murphy et al. 
2013, using core consistency values, peak picking, and sum of squares values. PARAFAC models were validated using split-half analysis, which was performed to authenticate each model (Murphy et al. 2013). PARAFAC was rerun with EEMs for individual irradiation experiments as an extra validation process. Components generated for A. germinans and $J$. roemerianus individual PARAFAC models were consistent with the overall model, although degradation rates for samples in each of the experiments varied (Fig. S1 and S2; Table 1 and S3). Components were identified through various sources (see Table 1) or were matched within the Openfluor Database using a certainty score of 0.97 , if not already identified (Murphy et al. 2014). Additionally, maximum fluorescence (Fmax) values for PARAFAC components were used to calculate average \% change in fluorescence over the 20-h irradiation period in all components (Table 3 ).

It is important to note that "humic-like" is a term used generally in PARAFAC analyses to describe humic substances within a wide range of excitation and emissions wavelengths (Ex: 260, 350, Em: 380-460, 420-480, Coble 1996). However, this term remains practically defined without any real chemical meaning, because fluorophore structures remain unknown, but are generally well correlated with the polyphenolic content in freshwater systems (Jaffé et al. 2020). Hence, the generic humic material signal is likely reflecting a solubilized and highly degraded polyphenolic material. It is unlikely that leaf leachates contain similar degraded and water-soluble polyphenols, but similar fluorescence can still be observed, which underlines the dilemma of source tracking based on fluorescence. However, for simplicity reasons and in order to compare photochemicallyinduced changes and samples across this study and others, the term "humic-like" is still used in this manuscript as an indication of the differences or similarities to other PARAFAC models.

\section{Changes in optical properties}

Absorbance and differential absorbance curves were graphed to observe changes in absorbance across wavelengths over time. Wavelength $a(300)$ was chosen for detailed plotting and analysis because all samples displayed the largest absolute differences in fluorescence intensity within this excitation range. In addition, $a(300)$ is in the UV-B range which is amongst the most energetic wavelengths that reach the Earth's surface, and therefore the most likely to cause rapid photodegradation (Weishaar et al. 2003). Optical property changes were monitored for absorption coefficients at $a(300)$, normalized to $\mathrm{T}=0$, and visualized in R (Ver 3.5.2, R Foundation for Statistical Computing, Vienna Austria), over the 20-h irradiation interval (Fig. 4). Fmax values generated from PARAFAC analysis were also normalized to $\mathrm{T}=0$ and visualized in $\mathrm{R}$ (Fig. 8). Data used to generate curves for $a(300)$ was also used to calculate average \% change in absorbance across $20 \mathrm{~h}$ of irradiation (Table 2).

\section{Results}

Absorbance curves across the spectrum $a(230-700)$ and specifically at $a(300)$

Absorbance curves displayed a visible difference between species and water treatment across the entire measured spectrum $a(230-700)$. Differential absorbance over time exhibited the largest absolute changes in absorbance primarily between $a(250-400)$ (Fig. 3). A. germinans DOM displayed largest decrease in absorbance between wavelengths $a(300-350)$ in freshwater and $a(350-400)$ in saltwater, but A.germinans appeared to photo-degrade more rapidly in the higher salinity samples between $a(350-500)$ than in freshwater diluted DOM (Fig. 3a, b). In the visible wavelengths $a(400-700)$, freshwater diluted A.germinans DOM does not show a decrease in absorbance over time, whereas the saltwater diluted A.germinans DOM continues to degrade across those wavelengths. $J$. roemerianus DOM displays a similar trend to $A$. germinans but $J$. roemerianus shows a lower overall change in absorbance (Fig. 3c, d). Taxodium distichum diluted in DI water appeared to have increasing absorbance across the entire spectrum throughout the 20-h irradiation period, and this increase is significant for the $a(250-350)$ region (Fig. 3e). However, the absorbance change for $T$. distichum appears to be less pronounced and even minimal in seawater (Fig. 3e, f).

At $a(300), A$. germinans and $J$. roemerianus presented more consistency between DI and saltwater replicates (Fig. 4a, b; Table 2). Absorbance in both species in DI and seawater diluted samples decreased 


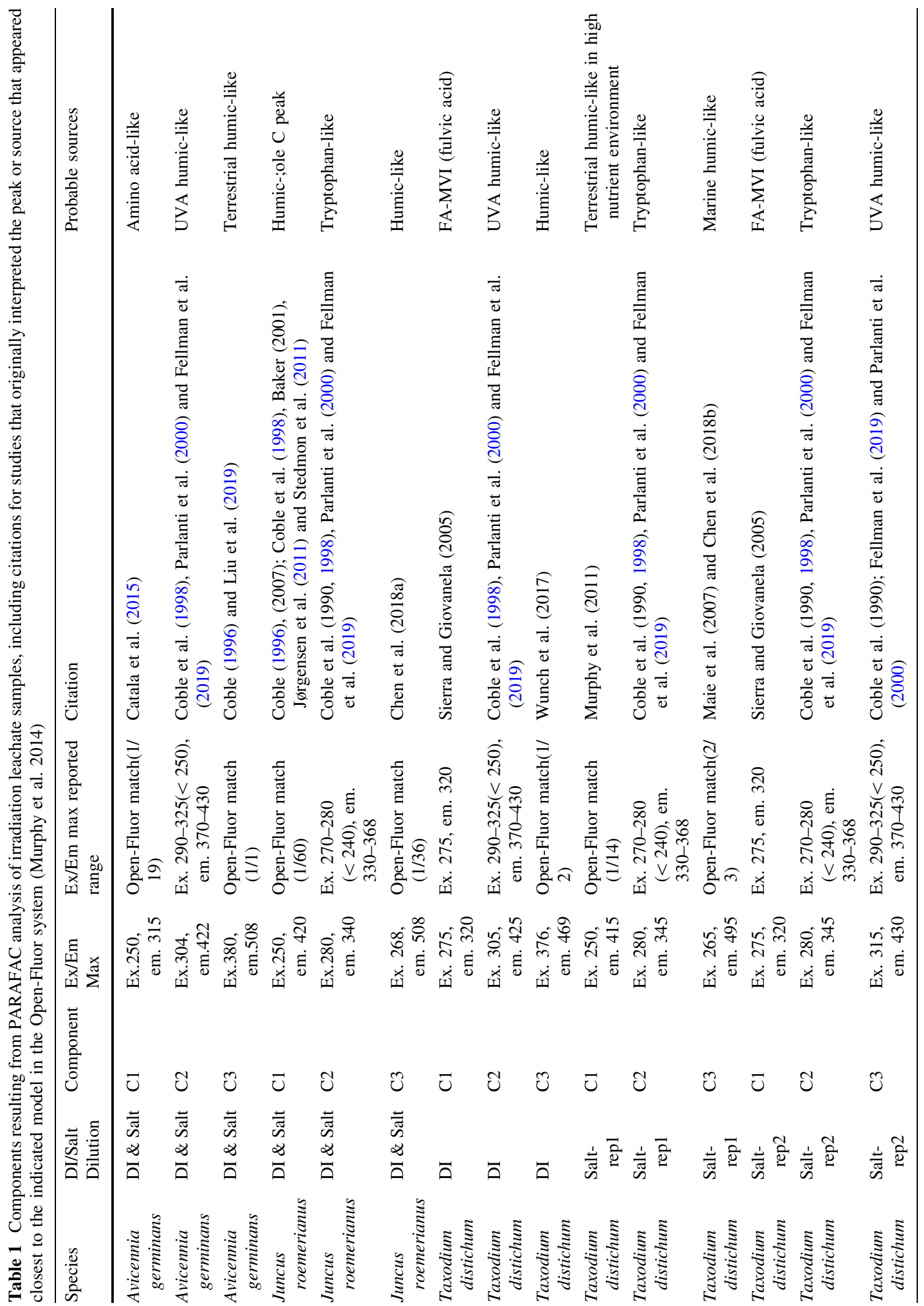


Table 2 Average \% loss or gain of absorbance at $a(300)$ over the 20-h irradiation period

\begin{tabular}{lcc}
\hline Sample & $\mathrm{a}(300)$ fresh & $\mathrm{a}(300)$ salt \\
\hline A. germinans & $-18(1)$ & $-15(4)$ \\
J. roemerianus & $-13(0.9)$ & $-19(0.4)$ \\
T. distichum & $30(0.8)$ & $-3(0.5)$ \\
\hline
\end{tabular}

Numbers in parenthesis are the calculated standard deviation

over the 20-h interval. All treatments of A. germinans and $J$. roemerianus decreased in absorbance between 13 and $18 \%$ at $a(300)$. However, T. distichum freshwater diluted samples increased by $30 \%$, whereas saltwater samples decreased in absorbance by only $3 \%$ over the entire 20-h interval (Fig. 5c; Table 2).

Fluorescence, PARAFAC, and component degradation curves

Fluorescent properties of A. germinans, J. roemerianus, and $T$. distichum were unique to each species. All three species displayed diverse patterns of fluorescence and photo-degradation as displayed by EEMs (Figs. 5, 6, 7). PARAFAC analysis resulted in the generation of three components for each species, $A$. germinans and $J$. roemerianus yielding the same components (based on similarity in OpenFluor) across treatments and $T$. distichum producing slightly different compilations of components between DI and saltwater treatments and between saltwater replicates (Fig. S1-S3). PARAFAC analysis for all treatments in A. germinans resulted overall in three distinct statistical components (Table 1). PARAFAC analysis for both DI diluted replicates of $T$. distichum resulted in slightly different components. $T$. distichum saltwater diluted replicate 1 irradiation experiment again resulted in slightly different components. These different PARAFAC models reflect the expected differences in photochemistry depending on water matrix.

The percent change in Fmax over the irradiation interval varied between species and components (Table 3). T. distichum saltwater treatments \% change in components Fmax were not averaged due to differences in PARAFAC components outlined above. No commonalities in $\%$ change of components were noticed between species, treatments, or components.

\section{Discussion}

Increasing salinity affects photodegradation of DOM from various sources in complex ways that are not yet fully understood. Chloride and bromide ions increase absorbance and increase photo-bleaching in water samples (Grebel et al. 2009), as shown in J. roemerianus and A. germinans leachates (Figs. 2, 3). However, T. distichum reacted differently, showing increased absorbance intensity across the 20-h irradiation period in freshwater samples but not saltwater samples (Fig. 3). Additionally, at least one component of all species displayed some difference in photodegradation patterns of fluorescent components between treatments (Table 1), and the increased photo-degradation of fluorophores at higher salinities could be due to increases in reactive oxygen species that form in the presence of salt (Osburn et al. 2009; Mostofa et al. 2013; Yang et al. 2014b). CDOM absorption loss at $440 \mathrm{~nm}$ has been shown to degrade $10-40 \%$ faster in saline water as opposed to fresh, indicating more rapid photo-bleaching in saline waters at longer wavelengths (Osburn et al. 2009). However, photo-bleaching was $20 \%$ higher at $280 \mathrm{~nm}$ at salinity 0 psu than 14 in a conflicting study conducted in the Great Dismal Swamp, indicating increased resistance to photodegradation in terrestrially derived DOM with increasing salinity. This study was conducted on bulk water, containing DOM from a wide variety of sources in a unique system as opposed to solely one species (Minor et al. 2006a). The intricacies and unique photosensitivity of DOM from various sources exhibit distinct reactions to salinity, depending on chromophore and fluorophore sources (Yang et al. 2014b).

Although already commonly accepted, this study further solidifies the idea that photo-degradation of primary source material is species specific. Leachate photochemistry has already been established as seasonally specific due to senesce and seasonal growth patterns of source vegetation, altering DOM properties and concentration throughout the year (Wheeler et al. 2017). Variability between species indicates that irradiation studies conducted on whole water samples do not capture the intricacies and variability that can be present across a study site, especially riverine/ estuarine systems since species compositions can change rapidly across the aquatic continuum (Vannote et al. 1980; Webster et al. 2016). For example, a study examining photo-kinetics of red mangrove 

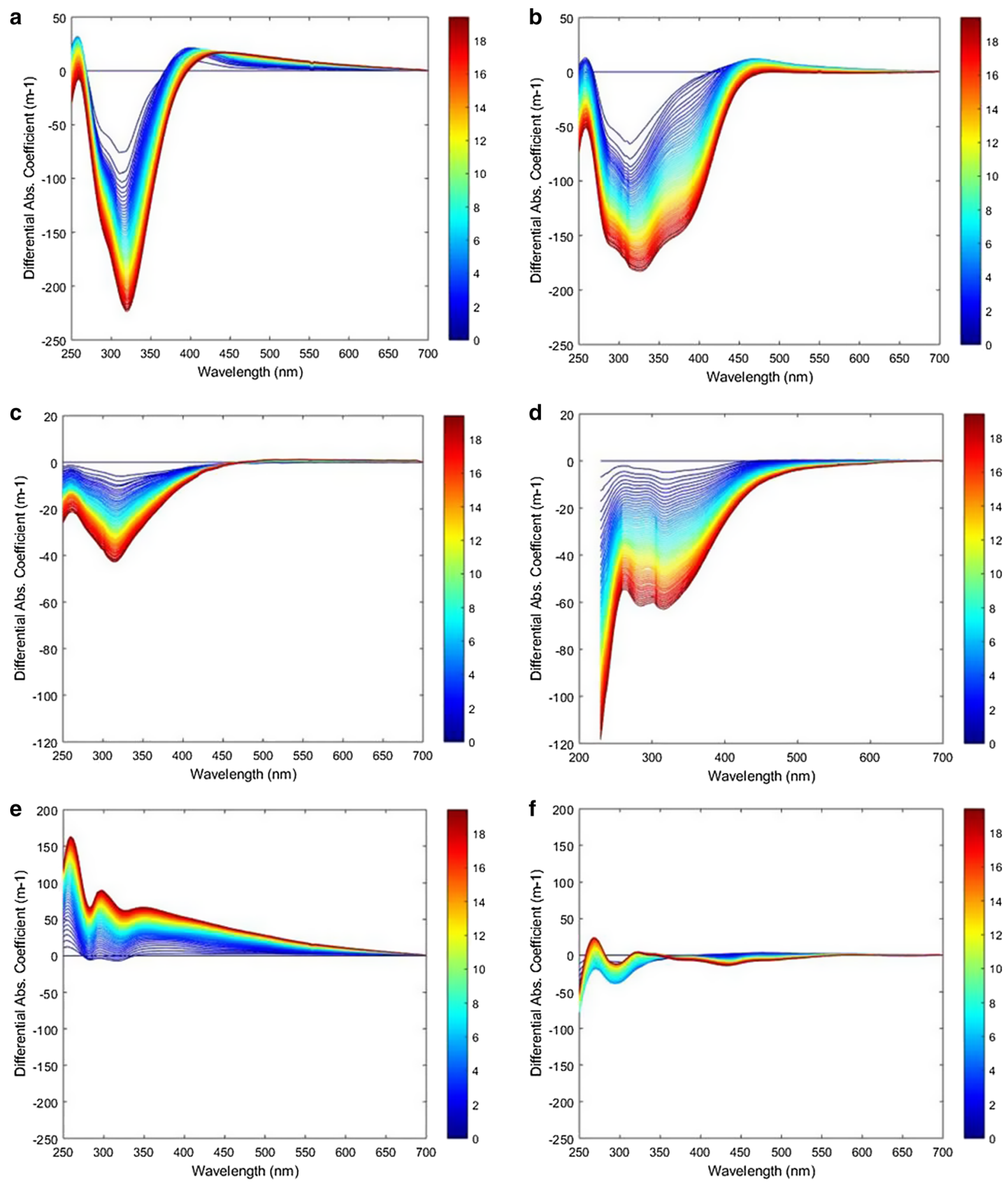

Fig. 3 Differential absorption coefficients $\left(\mathrm{m}^{-1}\right)(a(\lambda) \mathrm{t}-$ $a(\lambda) \mathrm{t}=0)$ in fresh and saltwater diluted samples over $\lambda=250-700 \mathrm{~nm}$. a Avicennia germinans fresh water $\mathbf{b}$ Avicennia germinans salt water c Juncus roemerianus fresh water

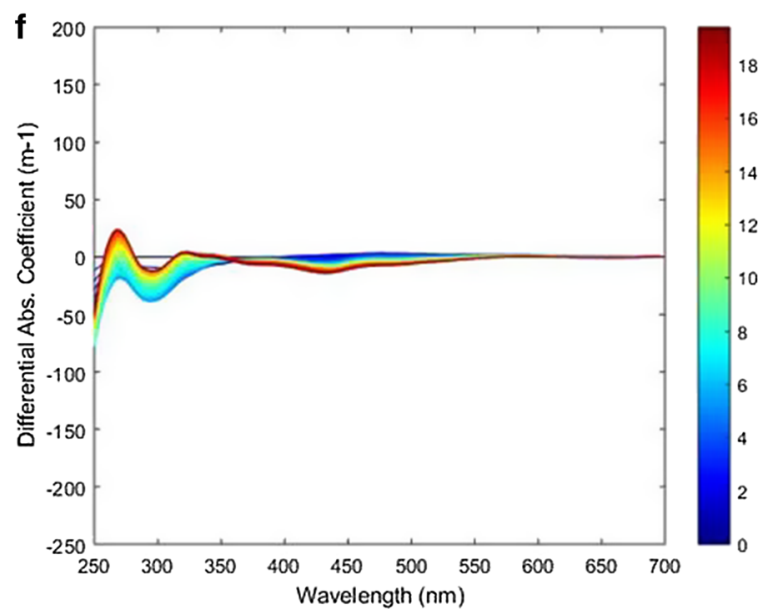

d Juncus roemerianus salt water e Taxodium distichum fresh water f. Taxodium distichum salt water as irradiated over $20 \mathrm{~h}$. Color bar represents time in hours 
Fig. 4 Decay curves and replicates for a Avicennia germinans, b Juncus roemerianus, and c Taxodium distichum freshwater and saltwater irradiation experiments at wavelength 300 normalized for T0
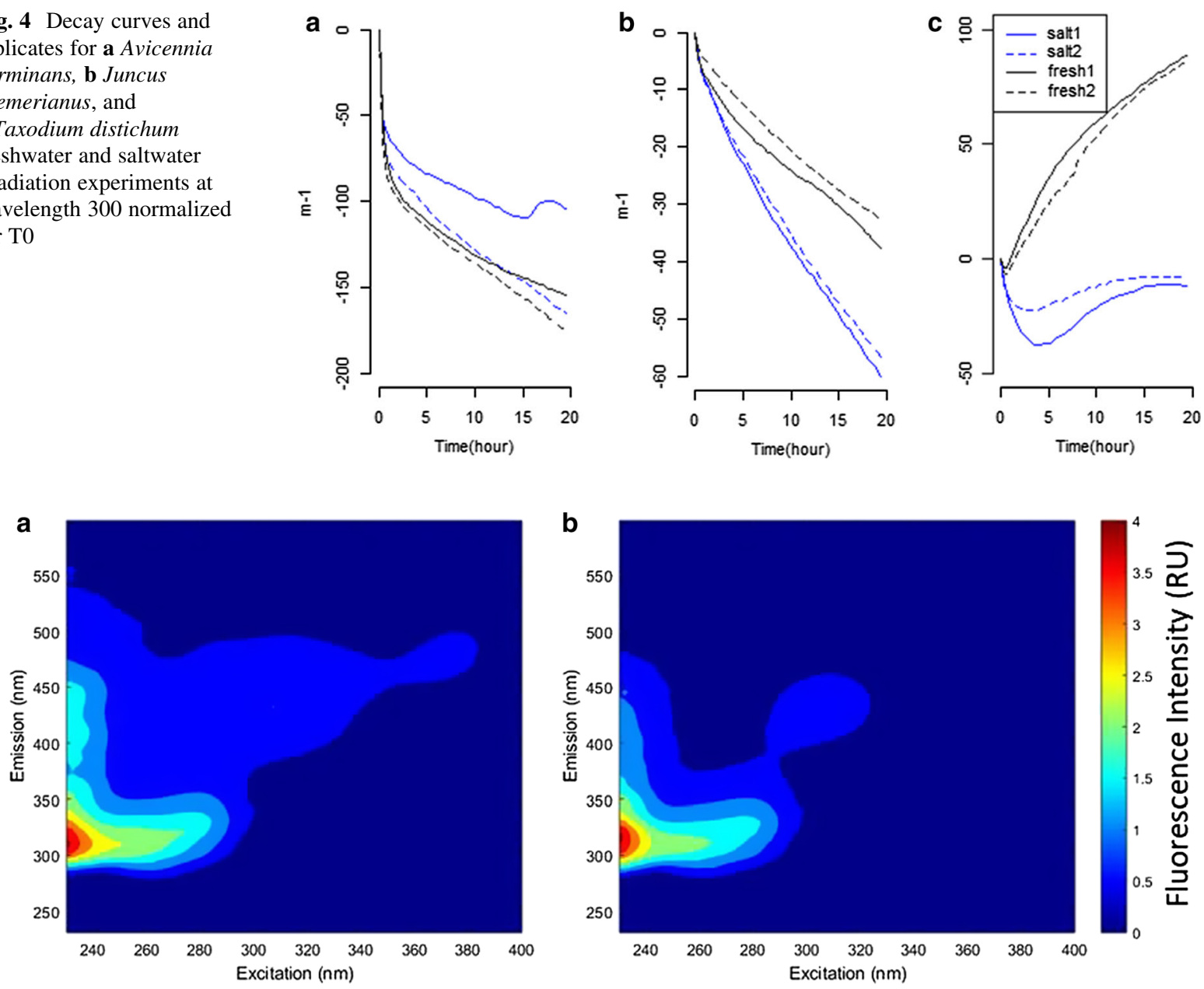

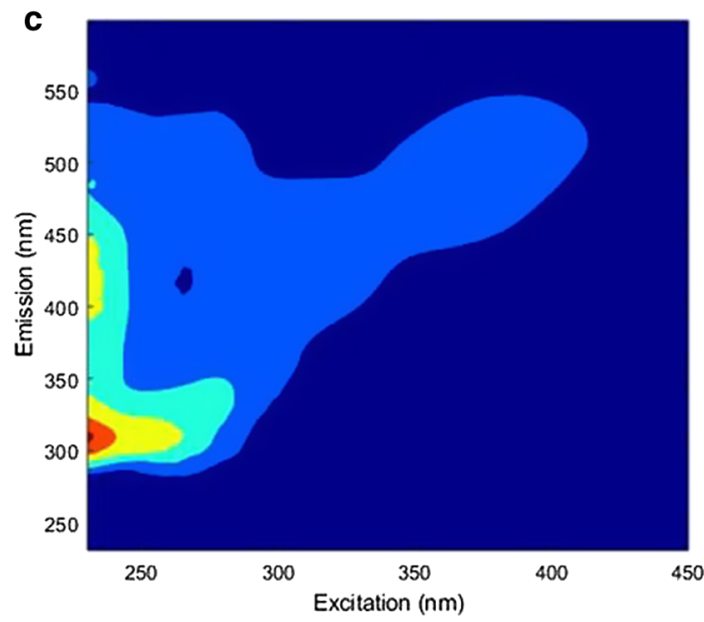

Fig. 5 EMS depicting Avicennia germinans leachate fluorescence before and after irradiation. a Leachate diluted with deionized water before irradiation. b Leachate diluted with

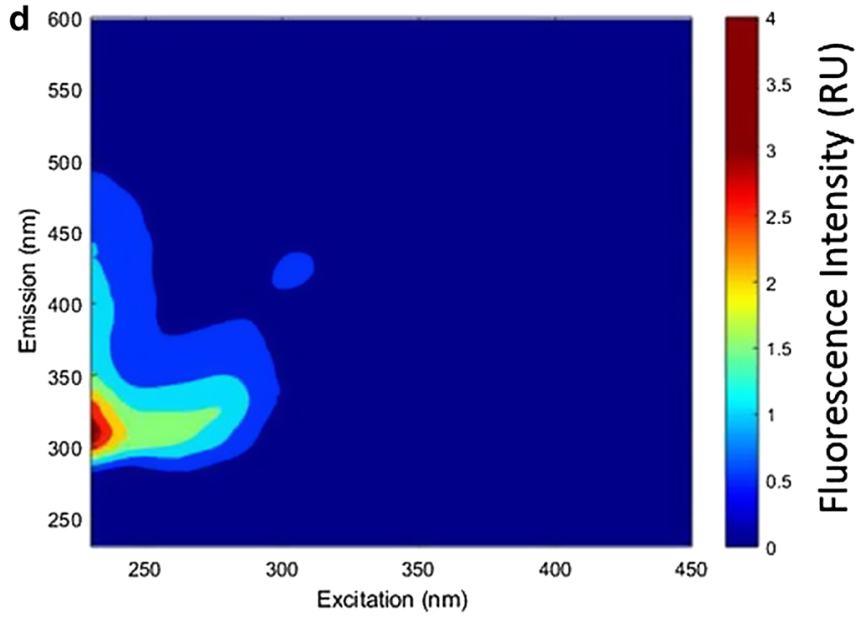

deionized water after irradiation. c Leachate diluted with sterilized seawater before irradiation. d Leachate diluted with sterilized seawater after irradiation 

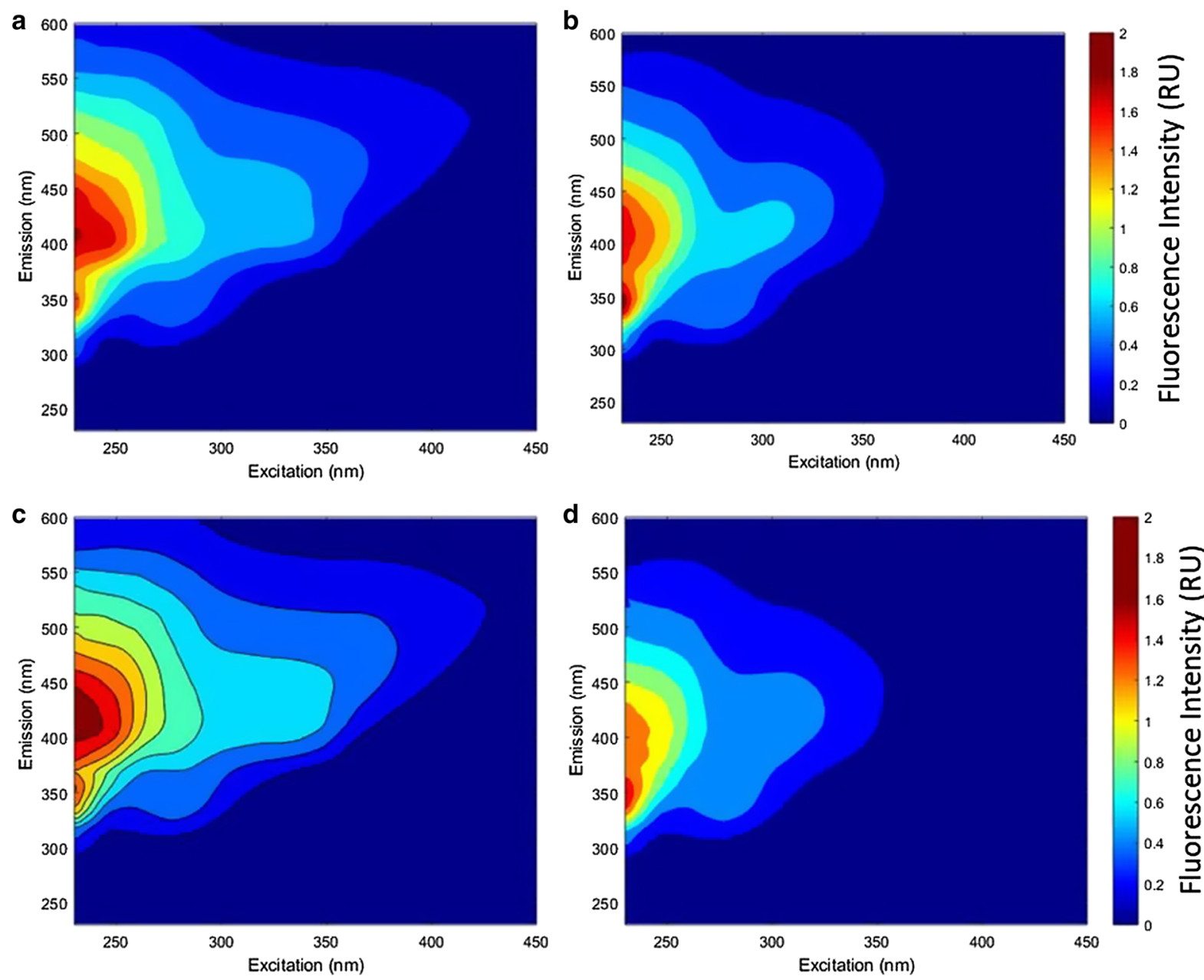

Fig. 6 EEMs depicting Juncus roemerianus leachate fluorescence before and after irradiation. a Leachate diluted with deionized water before irradiation. b Leachate diluted with

(Rhizophera mangle) and Sargassum spp. leachate observed very different degradation half-lives between the two species, mangrove leachate half-lives varying by senescence from $<50 \mathrm{~h}$ (brown leaveslate senescence) and 60-90 h (yellow-orange- early senescence), and Sargassum leachate exhibiting less variability and a half-life of $<40 \mathrm{~h}$ (Shank et al. 2010). Additionally, a study exploring photochemical properties of water, soil leachate, and vegetation leachates from sawgrass (Cladium jamaicense), spikerush (Elocharis cellulosa), red mangrove, and one species of seagrass (Thalassia testudinidum) discovered a large difference in photo-reactivity after 7 days of irradiation, exhibiting higher photo-reactivity of soil and vegetative leachates than bulk water (Chen

deionized water after irradiation. c Leachate diluted with sterilized seawater before irradiation. d Leachate diluted with sterilized seawater after irradiation

and Jaffé 2014). Results of this study in addition to the ones outlined above, indicate the necessity for further in-depth analysis on DOM from specific vegetation or soil types in order to aid researchers in identifying specific source material in bulk water samples. EEMPARAFAC remains a useful tool in determining bulk fluorescence and photo-induces changes in DOM associated with specific sources and more sourcespecific studies would add value to data repositories, such as the Openfluor system (Murphy et al. 2008).

Across the most explored and reactive wavelengths in the UV region and the components generated from the PARAFAC analysis, clear differences are observed between species. Although all leachate types and treatments were most reactive in the lower 

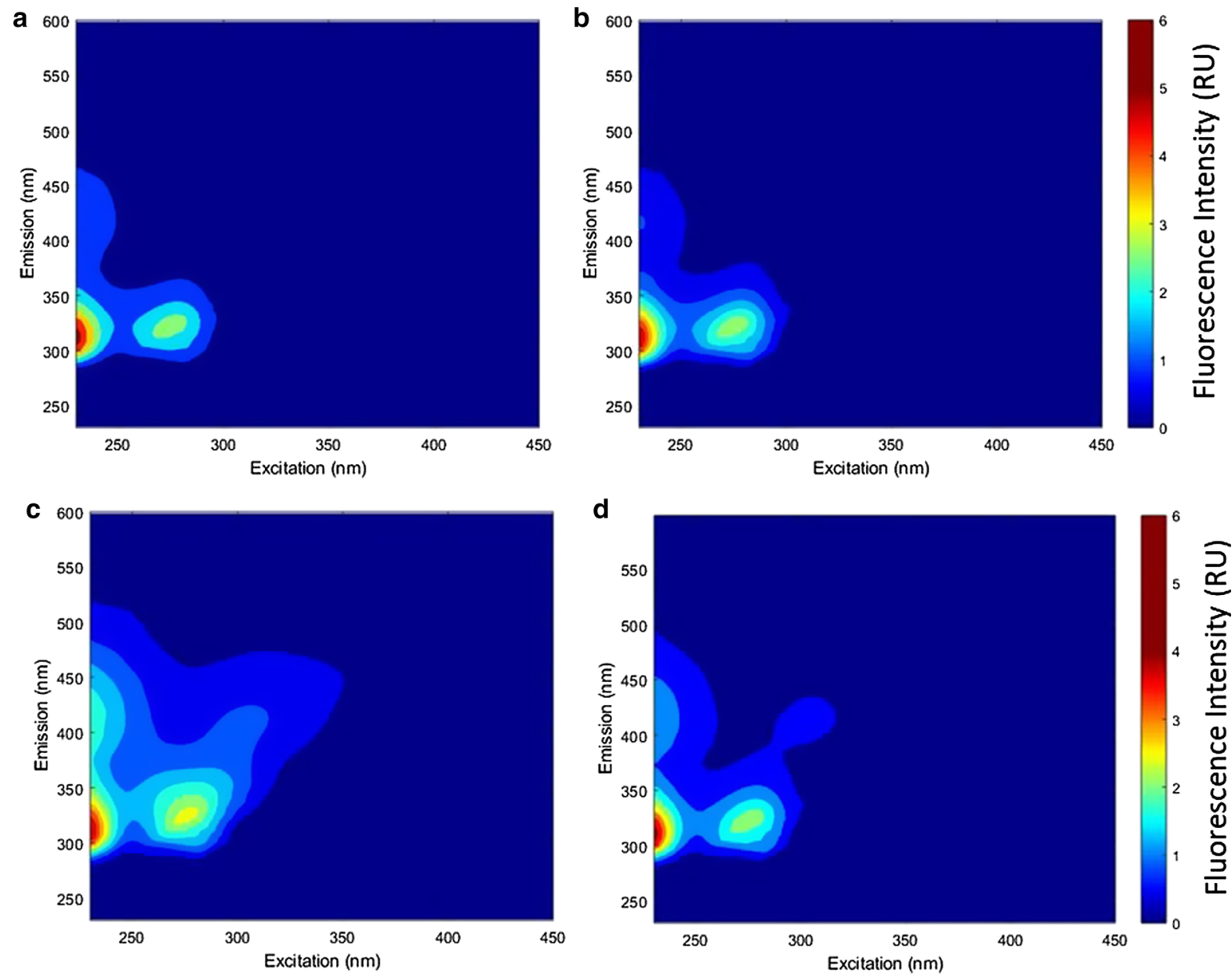

Fig. 7 EEMs depicting Taxodium distichum leachate fluorescence before and after irradiation. a Leachate diluted with deionized water before irradiation. b Leachate diluted with

wavelength range $a(250-400)$, there were apparent differences in absorbance and fluorescence spectra (Figs. 3, 5, 6, 7, 8). Additionally, none of the primary components were the same across species, as $\mathrm{C} 1$ for $A$. germinans was "amino-acid like", J. roemerianus was "humic-like", and $T$. distichum was variable with either "fulvic acid-like" or "terrestrial humic-like", when compared to available literature classifications. Although differences in components were seen across species, only $T$. distichum clearly revealed differences in primary source material leached in DI as opposed to saltwater (Table 1; Fig. 7). A. germinans and $J$. roemerianus inhabit saline environments and chemically and biologically adapted to survive in these environments (Touchette 2006; Liang et al. 2008). Potentially, due to these adaptations, the leachates

deionized water after irradiation. c Leachate diluted with sterilized seawater before irradiation. d Leachate diluted with sterilized seawater after irradiation

created from these two species are more resistant to effects of saltwater during leaching and irradiation. $A$. germinans can grow in soil salinities up to 90 psu and can osmotically adjust salt concentrations in cells in order to survive in varying salinity concentrations (Suárez et al. 1998; Suárez and Medina 2005; Liang et al. 2008); therefore, A. germinans is resistant to leaching and possibly degradation at higher salinity at the cellular level. T. distichum is non- halophytic and does not have waxy leaves or the ability to adjust cellular salinity as an adaptation to saltwater (Thomas et al. 2015). T. distichum is not considered to have the ability to exclude salt ions, excrete salt through leaves, or compartmentalize them in cell vacuoles like halophytes (Allen et al. 1996). Therefore, T. distichcum roots, leaves, etc. are not adapted to maintain 
Table 3 Average \% loss or gain of maximum fluorescence over the 20 -h irradiation period
Components for salt treatment $T$. distichum are not averaged since the components are not the same between runs

\begin{tabular}{|c|c|c|c|}
\hline Sample & Component & Ave. \% Change & (SD) \\
\hline A. germinans fresh & $\mathrm{C} 1$ & -4 & (7) \\
\hline A. germinans fresh & $\mathrm{C} 2$ & -34 & (4) \\
\hline A. germinans fresh & $\mathrm{C} 3$ & -69 & (6) \\
\hline A. germinans salt & $\mathrm{C} 1$ & 1 & (11) \\
\hline A. germinans salt & $\mathrm{C} 2$ & -42 & (4) \\
\hline A. germinans salt & $\mathrm{C} 3$ & -77 & $(0)$ \\
\hline J. roemerianus fresh & $\mathrm{C} 1$ & -25 & (1) \\
\hline J. roemerianus fresh & $\mathrm{C} 2$ & 11 & (4) \\
\hline J. roemerianus fresh & $\mathrm{C} 3$ & -69 & $(0)$ \\
\hline J. roemerianus salt & $\mathrm{C} 1$ & -40 & (1) \\
\hline J. roemerianus salt & $\mathrm{C} 2$ & 3 & (2) \\
\hline$J$. roemerianus salt & $\mathrm{C} 3$ & -78 & (1) \\
\hline Taxodium distichum fresh & $\mathrm{C} 1$ & -20 & (1) \\
\hline Taxodium distichum fresh & $\mathrm{C} 2$ & -43 & (1) \\
\hline Taxodium distichum fresh & $\mathrm{C} 3$ & -67 & (4) \\
\hline Taxodium distichum salt1 & $\mathrm{C} 1$ & -39 & (NA) \\
\hline Taxodium distichum salt 1 & $\mathrm{C} 2$ & -27 & (NA) \\
\hline Taxodium distichum salt1 & $\mathrm{C} 3$ & 2 & (NA) \\
\hline Taxodium distichum salt 2 & $\mathrm{C} 1$ & -61 & (NA) \\
\hline Taxodium distichum salt 2 & $\mathrm{C} 2$ & -79 & (NA) \\
\hline Taxodium distichum salt 2 & $\mathrm{C} 3$ & -49 & (NA) \\
\hline
\end{tabular}

osmotic balance under saline conditions, making $T$. distichcum OM more susceptible to leaching and degradation under saline conditions.

Disturbance events transports fresh OM into waterways and affects salinity regimes in a number of ways that can influence DOM characteristics and reactivity. Wind and precipitation are primary drivers of many disturbance events, which have the power to add large fluxes of OM to riverine systems rapidly and drive seawater further inland into freshwater areas. Photodegradation of fresh or normally photo-resistant compounds might occur with seawater incursion, since salt can increase photo-reactivity which effects the structure of DOM, increasing availability of material to further biotic degradation (Obernosterer and Benner 2004). After passage of a disturbance, such as a hurricane, salinity decreases due to runoff that transports additional large pulses of fresh OM into the waterway (Raymond et al. 2016). Reduced residence times from rapid export of $\mathrm{OM}$ into estuarine environments also has the capability to transport more allochthonous freshwater DOM into saline environments.
Hurricanes are likely one of the largest disturbances that lead to increases in DOM input and changes in salinity concentration. Hurricane events cause rapid changes in water chemistry, especially salinity, that can drastically change the matrix of CDOM (Schafer et al. 2020). Hurricanes may cause temporary dilution of coastal brackish environments and an associated decrease in salinity as seen post-Hurricane Irma (Schafer et al. 2020). However, these impacts are storm-dependent and a contrasting effect might instead temporarily increase salinity through winddriven surges of seawater moving inland as was seen during Hurricane Francis and Hurricane Irma in Florida (Bonvillain et al. 2011; Edmiston et al. 2008; Schafer et al. 2020). Salinity has been shown to substantially affect longwave (>350 nm) CDOM photobleaching, and CDOM absorption decreased by $10 \%$ to $40 \%$ as salinity was increased from 0 to 33 at $440 \mathrm{~nm}$ (Osburn et al. 2009). Decreases in CDOM photobleaching at $280 \mathrm{~nm}$ has also been shown when humic-rich CDOM was added to a salinity gradient that simulated estuarine mixing (Minor et al. 2006b). Quantum yields for photobleaching and hydrogen peroxide production have also been shown to increase 
Fig. 8 Component degradation curves normalized to $\mathrm{T} 0$ for a Avicennia germinans, b Juncus roemerianus, and c Taxodium distichum
C1
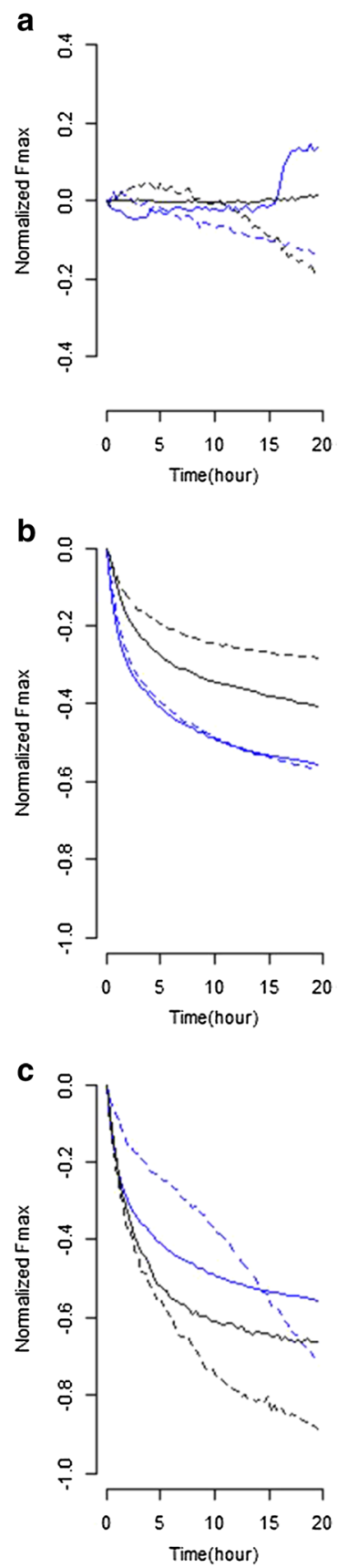

with salinity as an indicator of higher photo-reactivity (Osburn et al. 2009). Decreasing chromophoric and fluorescence intensities have been documented in salinities $>20$ photobleached samples, but the extent of these affects were observed to be dependent on specific chromophores and fluorophores (Yang et al.
C2
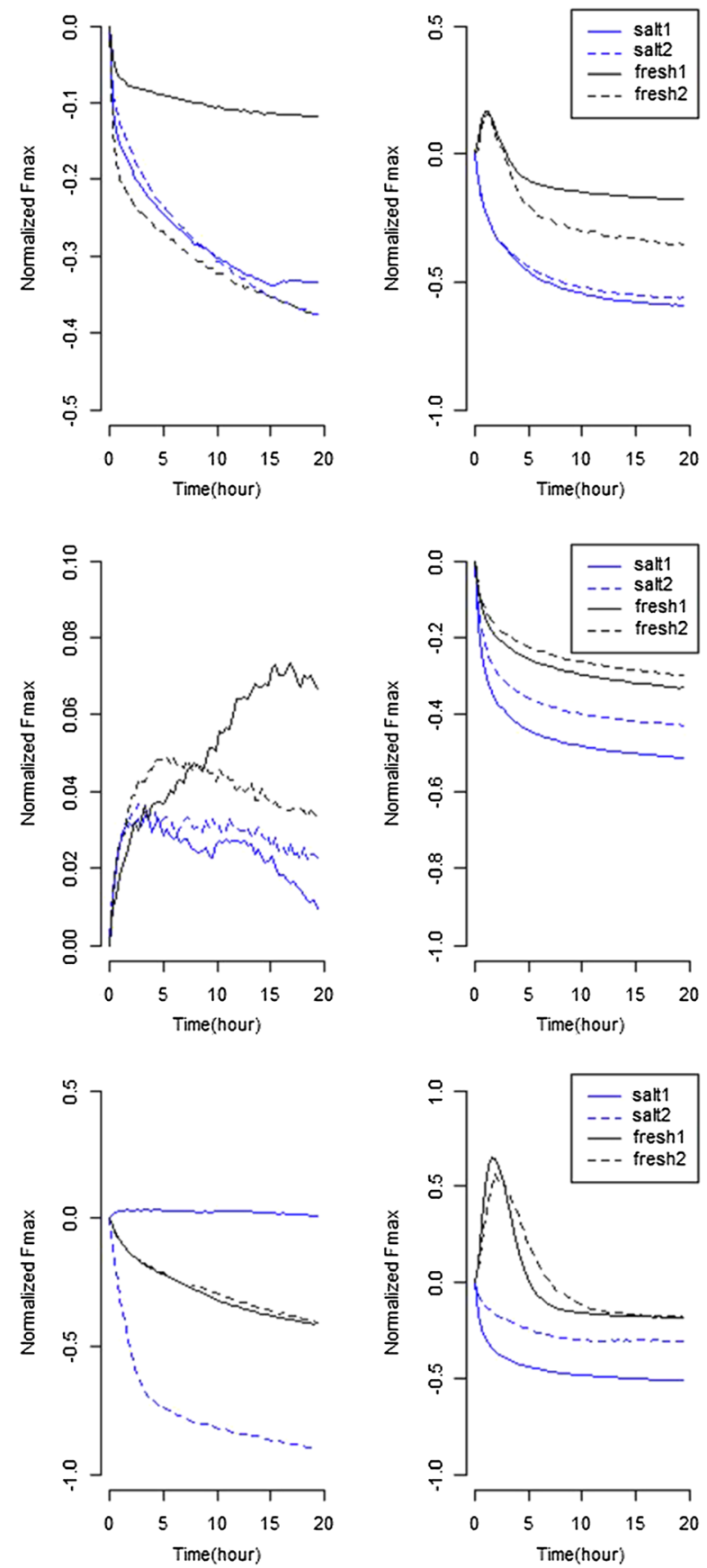

2014a). The delicate effect of $\mathrm{pH}$ changes associated with increase in alkalinity (Timko et al. 2015) as well as drastic changes in ionic strength and dissolved inorganic constituents are all factors fundamentally changing photodegradation of CDOM with increasing salinity (Grebel et al. 2009). 


\section{Conclusion}

There are increasing numbers of studies on the photokinetics, photo-degradation, and photo-transformation of DOM in natural systems. However, previous studies have primarily focused on the photochemistry of bulk DOM, and few have looked at specific sources such as leaf leachates. This study suggests that individual DOM sources will vary in reactivity to light, indicating a lack of understanding about the contribution of each constituent to the photoreactive DOM pool. DOM derived from Avicennia germinans and Juncus roemerianus, two salt-tolerant angiosperm species, yielded similar PARAFAC components and photodegradation patterns overtime. However, Taxodium distichum, a freshwater gymnosperm, displayed drastically different photochemical properties in terms of degradation patterns and PARAFAC components during irradiation. The differences in morphology of plant species, potentially the differences between angiosperms and gymnosperms, may create some vegetative leachates that resist photo-degradation under disturbed conditions, such as during saline intrusion from hurricanes and sea level rise.

Acknowledgements This work was made possible in part by a research Grant from the South Florida Water Management District (Award\# 9500006459).

Funding This work was made possible in part by a research grant from the South Florida Water Management District (Award\# 9500006459).

\section{Code availability Matlab, DREEM tutorial.}

\section{Compliance with ethical standards}

Conflict of interest All the authors declared that they have no conflict of interest.

Open Access This article is licensed under a Creative Commons Attribution 4.0 International License, which permits use, sharing, adaptation, distribution and reproduction in any medium or format, as long as you give appropriate credit to the original author(s) and the source, provide a link to the Creative Commons licence, and indicate if changes were made. The images or other third party material in this article are included in the article's Creative Commons licence, unless indicated otherwise in a credit line to the material. If material is not included in the article's Creative Commons licence and your intended use is not permitted by statutory regulation or exceeds the permitted use, you will need to obtain permission directly from the copyright holder. To view a copy of this licence, visit http://creativecommons.org/licenses/by/4.0/.

\section{References}

Allen JA, Pezeshki SR, Chambers JL (1996) Interaction of flooding and salinity stress on baldcypress (Taxodium distichum). Tree Physiol 16:307-313

Beggs KMH, Summers RS (2011) Character and chlorine reactivity of dissolved organic matter from a Mountain Pine beetle impacted watershed. Environ Sci Technol 45:5717-5724. https://doi.org/10.1021/es1042436

Bonvillain CP, Halloran BT, Boswell KM et al (2011) Acute physicochemical effects in a large river-floodplain system associated with the passage of hurricane gustav. Wetlands 31:979-987. https://doi.org/10.1007/s13157-011-0213-4

Catala TS, Reche I, Fuentes-lema A et al (2015) Turnover time of fluorescent dissolved organic matter in the dark global ocean. Nat Commun. https://doi.org/10.1038/ncomms6986

Chen M, Jaffé R (2016) Quantitative assessment of photo- and bio-reactivity of chromophoric and fluorescent dissolved organic matter from biomass and soil leachates and from surface waters in a subtropical wetland. Biogeochemistry. https://doi.org/10.1007/s10533-016-0231-7

Chen M, Jaffé R (2014) Photo- and bio-reactivity patterns of dissolved organic matter from biomass and soil leachates and surface waters in a subtropical wetland. Water Res 61:181-190. https://doi.org/10.1016/j.watres.2014.03.075

Coble PG (1996) Characterization of marine and terrestrial DOM in seawater using excitation-emission matrix spectroscopy. Mar Chem. https://doi.org/10.1016/03044203(95)00062-3

Coble PG, Del Castillo CE, Avril B (1998) Distribution and optical properties of CDOM in the Arabian Sea during the 1995 Southwest Monsoon. Deep Res Part II Top Stud Oceanogr. https://doi.org/10.1016/S0967-0645(98)00068$\mathrm{X}$

Cuss CW, Shi YX, McConnell SM, Gueguen C (2014) Changes in the fluorescence composition of multiple DOM sources over $\mathrm{pH}$ gradients assessed by combining parallel factor analysis and self-organizing maps. J Geophys Res Biogeosci 119:1850-1860. https://doi.org/10.1002/ 2013JG002598.Received

Edmiston HL, Fahrny SA, Lamb MS et al (2008) Tropical storm and hurricane impacts on a Gulf Coast Estuary: Apalachicola Bay, Florida. J Coast Res 10055:38-49. https:// doi.org/10.2112/SI55-009.1

Engelhaupt E, Bianchi TS, Wetzel RG, Tarr MA (2003) Photochemical transformations and bacterial utilization of high-molecular-weight dissolved organic carbon in a southern Louisiana tidal stream (Bayou Trepagnier). Biogeochemistry 62:39-58. https://doi.org/10.1023/A: 1021176531598

Fellman JB, Hood E, Spencer RGM (2019) Fluorescence spectroscopy opens new windows into dissolved organic matter dynamics in freshwater ecosystems: a review. Limnol Oceanogr 55:2452-2462. https://doi.org/10.4319/ lo.2010.55.6.2452

Fichot CG, Miller WL (2010) An approach to quantify depthresolved marine photochemical fluxes using remote sensing: Application to carbon monoxide (CO) photoproduction. Remote Sens Environ 114:1363-1377. https://doi.org/ 10.1016/j.rse.2010.01.019 
Grebel JE, Pignatello JJ, Song W et al (2009) Impact of halides on the photobleaching of dissolved organic matter. Mar Chem 115:134-144. https://doi.org/10.1016/j.marchem. 2009.07.009

Jaffé R, Cawley KM, Yamashita Y (2020) Applications of excitation emission matrix fluorescence with parallel factor analysis (EEM-PARAFAC) in assessing environmental dynamics of natural dissolved organic matter (DOM) in aquatic environments: a review. American Chemical Society, Washington DC

Jankowski JJ, Kieber DJ, Mopper K (1999) Nitrate and nitrite ultraviolet actinometers. Photochem Photobiol 70:319-328. https://doi.org/10.1111/j.1751-1097.1999. tb08143.x

Jankowski JJ, Kieber DJ, Mopper K, Neale PJ (2000) Development and intercalibration of ultraviolet solar actinometers. Photochem Photobiol 71:431. https://doi.org/10.1562/ 0031-8655(2000)071\%3c0431:daious\%3e2.0.co;2

Johannessen SC, Miller WL (2001) Quantum yield for the photochemical production of dissolved inorganic carbon in seawater. Mar Chem 76:271-283

Jørgensen L, Stedmon CA, Kragh T et al (2011) Global trends in the fluorescence characteristics and distribution of marine dissolved organic matter. Mar Chem 126:139-148. https:// doi.org/10.1016/j.marchem.2011.05.002

Larsen LG, Aiken GR, Harvey JW et al (2010) Using fluorescence spectroscopy to trace seasonal DOM dynamics, disturbance effects, and hydrologic transport in the Florida Everglades. J Geophys Res Biogeosci. https://doi.org/10. 1029/2009JG001140

Liang S, Zhou RC, Dong SS, Shi SH (2008) Adaptation to salinity in mangroves: implication on the evolution of salttolerance. Chin Sci Bull 53:1708-1715. https://doi.org/10. 1007/s11434-008-0221-9

Liu C, Du Y, Yin H et al (2019) Exchanges of nitrogen and phosphorus across the sediment-water interface influenced by the external suspended particulate matter and the residual matter after dredging. Environ Pollut 246:207-216. https://doi.org/10.1016/j.envpol.2018.11. 092

Miller WL, Moran MA, Sheldon WM et al (2002) Determination of apparent quantum yield spectra for the formation of biologically labile photoproducts. Limnol Oceanogr 47:343-352

Minor EC, Pothen J, Dalzell BJ et al (2006a) Effects of salinity changes on the photodegradation and ultraviolet-visible absorbance of terrestrial dissolved organic matter. Limnol Oceanogr 51:2181-2186

Minor EC, Simjouw JP, Mulholland MR (2006b) Seasonal variations in dissolved organic carbon concentrations and characteristics in a shallow coastal bay. Mar Chem 101:166-179. https://doi.org/10.1016/j.marchem.2006.02. 005

Mostofa KMG, Yoshioka T, Mottaleb MA, Vione D (2013) Photobiogeochemistry of organic matter: principles and practices in water. Springer, New York

Murphy KR, Stedmon CA, Graeber D, Bro R (2013) Fluorescence spectroscopy and multi-way techniques. PARAFAC Anal Methods 5:6557-6566. https://doi.org/10.1039/ c3ay41160e
Murphy KR, Stedmon CA, Waite TD, Ruiz GM (2008) Distinguishing between terrestrial and autochthonous organic matter sources in marine environments using fluorescence spectroscopy. Mar Chem 108:40-58. https://doi. org/10.1016/j.marchem.2007.10.003

Murphy KR, Stedmon CA, Wenig P, Bro R (2014) OpenFluorAn online spectral library of auto-fluorescence by organic compounds in the environment. Anal Methods 6:658-661. https://doi.org/10.1039/c3ay41935e

Obernosterer I, Benner R (2004) Competition between biological and photochemical processes in the mineralization of dissolved organic carbon. Limnol Oceanogr 49:117-124. https://doi.org/10.4319/lo.2004.49.1.0117

Osborne TZ, Inglett PW, Reddy KR (2007) The use of senescent plant biomass to investigate relationships between potential particulate and dissolved organic matter in a wetland ecosystem. Aquat Bot. https://doi.org/10.1016/j.aquabot. 2006.09.002

Osburn CL, Handsel LT, Mikan MP et al (2012) Fluorescence tracking of dissolved and particulate organic matter quality in a river-dominated estuary. Environ Sci Technol. https:// doi.org/10.1021/es3007723

Osburn CL, O'Sullivan DW, Boyd TJ (2009) Increases in the longwave photobleaching of chromophoric dissolved organic matter in coastal waters. Limnol Oceanogr 54:145-159

Osburn CL, Stedmon CA (2011) Linking the chemical and optical properties of dissolved organic matter in the Baltic - North Sea transition zone to differentiate three allochthonous inputs. Mar Chem 126:281-294. https://doi.org/ 10.1016/j.marchem.2011.06.007

Parlanti E, Woè K, Geoffroy L, Lamotte M (2000) Dissolved organic matter fluorescence spectroscopy as a tool to estimate biological activity in a coastal zone submitted to anthropogenic inputs. Org Geochem 31:1765-1781

Raymond PA, Saiers JE, Sobczak WV (2016) Hydrological and biogeochemical controls on watershed DOM transport: pulse-shunt concept. Ecology 97:5-16. https://doi.org/10. 1890/14-1684.1

Ruggaber A, Dlugi R, Nakajima T (1994) Modeling radiation quantities and photolysis frequencies in the troposphere. J Atmos Chem 18:171-210

Schafer T, Ward N, Julian P, et al (2020) Impacts of hurricane disturbance on water quality across the aquatic continuum of a blackwater river to estuary complex. J Mar Sci Eng https://doi.org/10.3390/JMSE8060412

Shank GC, Zepp RG, Vähätalo A et al (2010) Photobleaching kinetics of chromophoric dissolved organic matter derived from mangrove leaf litter and floating Sargassum colonies. Mar Chem 119:162-171. https://doi.org/10.1016/j. marchem.2010.01.003

Stedmon CA, Markager S, Tranvik L et al (2007) Photochemical production of ammonium and transformation of dissolved organic matter in the Baltic Sea. Mar Chem 104:227-240. https://doi.org/10.1016/j.marchem.2006.11.005

Stedmon CA, Tallec N Le, Waul CK, Arvin E (2011) A potential approach for monitoring drinking water quality from groundwater systems using organic matter fluorescence as an early warning for contamination events. Water Res 45:6030-6038. https://doi.org/10.1016/j.watres.2011.08. 066 
Stubbins A, Law CS, Mopper K et al (2006) Open-ocean carbon monoxide photoproduction. Deep Sea Res 53:1695-1705. https://doi.org/10.1016/j.dsr2.2006.05.011

Suárez N, Medina E (2005) Salinity effect on plant growth and leaf demography of the mangrove, Avicennia germinans L. Trees Struct Funct 19:721-727. https://doi.org/10.1007/ s00468-005-0001-y

Suárez N, Sobrado MA, Medina E (1998) Salinity effects on the leaf water relations components and ion accumulation patterns in Avicennia germinans (L.) L. seedlings. Oecologia 114:299-304. https://doi.org/10.1007/ s004420050451

Thomas BL, Doyle T, Krauss K (2015) Annual growth patterns of baldcypress (Taxodium distichum) along salinity gradients. Wetlands 35:831-839. https://doi.org/10.1007/ s13157-015-0659-x

Timko SA, Gonsior M, Cooper WJ (2015) Influence of pH on fluorescent dissolved organic matter photo-degradation. Water Res 85:266-274. https://doi.org/10.1016/j.watres. 2015.08.047

Toole DA, Slezak D, Kiene RP et al (2006) Effects of solar radiation on dimethylsulfide cycling in the western Atlantic Ocean. Deep Sea Res 53:136-153. https://doi.org/10.1016/ j.dsr.2005.09.003

Touchette BW (2006) Salt tolerance in a Juncus roemerianus brackish marsh: spatial variations in plant water relations. J Exp Mar Bio Ecol 337:1-12. https://doi.org/10.1016/j. jembe.2006.05.011

Vahatalo AV, Jarvinen M (2007) Photochemically produced bioavailable nitrogen from biologically recalcitrant dissolved organic matter stimulates production of a nitrogenlimited microbial food web in the Baltic Sea. Limnol Oceanogr 52:132-143

Vannote RL, Minshall GW, Cummins KW et al (1980) The river continuum concept. Can J Fish Aquat Sci 37:130-137

Walsh JJ, Weisberg RH, Dieterle DA et al (2003) Phytoplankton response to intrusions of slope water on the West Florida Shelf: models and observations. J Geophys Res 108:1-23. https://doi.org/10.1029/2002JC001406
Webster J, Newbold J, Lin L (2016) Nutrient spiraling and transport in streams

Weishaar JL, Fram MS, Fujii R, Mopper K (2003) Evaluation of specific ultraviolet absorbance as an indicator of the chemical composition and reactivity of dissolved organic carbon. Environ Sci Technol 37:4702-4708. https://doi. org/10.1021/es030360x

Wetzel RG, Hatcher PG, Bianchi TS (1995) Natural photolysis by ultraviolet irradiance of recalcitrant dissolved organic matter to simple substrates for rapid bacterial metabolism. Limnol Oceangr 40:1369-1380

Wheeler KI, Levia DF, Hudson JE (2017) Tracking senescenceinduced patterns in leaf litter leachate using parallel factor analysis (PARAFAC) modeling and self-organizing maps. J Geophys Res Biogeosci 122:2233-2250. https://doi.org/ 10.1002/2016JG003677

Williamson CE, Neale PJ, Grad G et al (2001) Beneficial and detrimental effects of UV on aquatic organisms: implications of spectral variation. Ecol Appl 11:1843-1857

Yang X, Meng F, Huang G et al (2014a) Sunlight-induced changes in chromophores and fluorophores of wastewaterderived organic matter in receiving waters - The role of salinity. Water Res. https://doi.org/10.1016/j.watres.2014. 05.050

Yang X, Meng F, Huang G, Sun L (2014b) Sunlight-induced changes in chromophores and fluorophores of wastewaterderived organic matter in receiving waters: the role of salinity. Water Res 62:281-292. https://doi.org/10.1016/j. watres.2014.05.050

Zepp RG, Sheldon WM, Moran MA (2004) Dissolved organic fluorophores in southeastern US coastal waters: correction method for eliminating Rayleigh and Raman scattering peaks in excitation-emission matrices. Mar Chem 89:15-36. https://doi.org/10.1016/j.marchem.2004.02.006

Publisher's Note Springer Nature remains neutral with regard to jurisdictional claims in published maps and institutional affiliations. 